\title{
STUDY OF SELECTIVE HYDROGEN SULFIDE ABSORPTION BY COMPARING TWO DIFFERENT ALKALI ABSORBENTS BY USING ATOMIZATION METHOD
}

\author{
ÉVA MOLNÁR Ra, ", DÓRA RIPPEL-PETHÖa, GÉZA HORVÁTHa, \\ JANKA BOBEK ${ }^{\mathrm{a}}$, RÓBERT BOCSI ${ }^{\mathrm{a}}$, ZOLTÁN HODAl ${ }^{\mathrm{a}}$
}

\begin{abstract}
Significant part of the energy need of the world is covered by utilization of natural gas. Due to the hydrogen sulphide content of raw gas the natural gas industry has to tackle some serious problems, for example corrosion-, environmental-, economic- and safety engineering problems. Our aim is to develop the selective hydrogen sulfide absorption by using alkali solutions. Experiments were performed in a specially designed atomizing reactor by using potassium- and sodium hydroxide absorbents. During the tests the following parameters have changed: contact time, pressure, volumetric flow rate of gas and liquid, concentration and material quality of absorbents. Three different model gas mixtures were used for measurements; they consist of nitrogen, carbon dioxide and hydrogen sulfide.
\end{abstract}

Keywords: selectivity, absorption, hydrogen sulfide, carbon dioxide, sodium hydroxide, potassium hydroxide, atomization

\section{INTRODUCTION}

Nowadays several sour gas sweetening methods are known, but only few of these are selective, economic and able to fulfill the environmental regulations [1-7]. The technique based on competitive chemisorptions of hydrogen sulfide $\left(\mathrm{H}_{2} \mathrm{~S}\right)$ and carbon dioxide $\left(\mathrm{CO}_{2}\right)$ seems to be a good solution to meet these requirements [5-8]. The removal of $\mathrm{H}_{2} \mathrm{~S}$ together with other components (for example $\mathrm{CO}_{2}$ ) is often costly and not necessary, therefore the demand exist for selective absorption of $\mathrm{H}_{2} \mathrm{~S}$ from gas mixtures [6; 9]. Absorption in alkali hydroxides is able to work as a

\footnotetext{
a Institute of Chemical and Process Engineering, Department of Chemical Engineering Science, University of Pannonia, H-8200 Veszprém, Hungary.

Corresponding author: molnare@almos.uni-pannon.hu
} 
selective (for $\mathrm{H}_{2} \mathrm{~S}$ ) method if the appropriate conditions are provided [5-7; 10-12]. It is important that the contact of gas and liquid phase is realized quickly and intensively through large surface. This is necessary because of the difference of reaction time requirements of $\mathrm{H}_{2} \mathrm{~S}$ and $\mathrm{CO}_{2}$; furthermore with these conditions the operation can achieve high efficiency [5-7; 11-12]. Atomization methods are widely used in the chemical industry for absorption of gas components [9; 13-14]. The surface and droplet size are very substantial factors in these methods in terms of dissolution $[4 ; 9-10$; 13-14]. In addition, there are a lot of conditions which have a significant impact on mass transfer of gas purification in an atomizing apparatus, for example material quality, concentration, density, surface tension, viscosity, volumetric flow rate and $\mathrm{pH}$ value of absorbent; composition and flow of gas mixture; contact time and pressure [5; 13-16]. The following $\mathrm{pH}-$ dependent (1)-(8) reactions are considered to be important which occur within the alkali hydroxide solutions [10; 16].

$$
\begin{gathered}
\mathrm{H}_{2} \mathrm{~S}+\mathrm{OH}^{-} \rightarrow \mathrm{HS}^{-}+\mathrm{H}_{2} \mathrm{O} \\
\mathrm{CO}_{2}+\mathrm{OH}^{-} \rightarrow \mathrm{HCO}_{3}^{-} \\
\mathrm{HCO}_{3}{ }^{-}+\mathrm{OH}^{-} \rightarrow \mathrm{CO}_{3}{ }^{2-}+\mathrm{H}_{2} \mathrm{O} \\
\mathrm{H}_{2} \mathrm{O} \rightarrow \mathrm{H}^{+}+\mathrm{OH}^{-} \\
\mathrm{CO}_{3}{ }^{2-}+\mathrm{H}^{+} \rightarrow \mathrm{HCO}_{3}^{-} \\
\mathrm{H}_{2} \mathrm{~S}+\mathrm{CO}_{3}{ }^{2-} \rightarrow \mathrm{HS}^{-}+\mathrm{HCO}_{3}^{-} \\
\mathrm{CO}_{2}+\mathrm{H}_{2} \mathrm{O}+\mathrm{CO}_{3}{ }^{2-} \rightarrow 2 \mathrm{HCO}_{3}^{-} \\
\mathrm{H}_{2} \mathrm{~S}+2 \mathrm{OH}^{-} \rightarrow \mathrm{S}^{2-}+2 \mathrm{H}_{2} \mathrm{O}
\end{gathered}
$$

In terms of the consumption of caustic and selectivity the reaction (1) and (6) are most desirable and the reaction (2) and (7) are least preferred reactions $[10 ; 16]$.

\section{RESULTS AND DISCUSSION}

Experiments were performed to know the effect of contact time, pressure, gas flow, carbon dioxide content of gas mixtures, material quality, concentration and volumetric flow rate of alkali absorbent in that case if atomization method was used for contact of gas and liquid phases. Efficiency of process was examined as a function of the molar ratio of absorbent and hydrogen sulfide $\left(\mathrm{OH}^{-} / \mathrm{H}_{2} \mathrm{~S}\right.$ molar rate). The molar excess of absorbent is essential to ensure the efficient operation of system. For 
economical operation the goal is to maximize the efficiency of $\mathrm{H}_{2} \mathrm{~S}$ absorption by providing the smallest possible $\mathrm{OH}^{-} / \mathrm{H}_{2} \mathrm{~S}$ molar rate.

\section{Impact of contact time and pressure at a constant gas flow rate}

The contact time changes together with pressure at a given constant volumetric gas flow rate. As it is known the decrease of contact time favors for $\mathrm{H}_{2} \mathrm{~S}$ removal and not the $\mathrm{CO}_{2}$ absorption. The effect of contact time $(0,12-$ $0,27 \mathrm{~s})$ and pressure (4-10bar) at a constant gas flow rate $\left(0,8 \mathrm{Nm}^{3} / \mathrm{h}\right)$ is shown in Figure 1-4 (in these case the concentration of $\mathrm{NaOH}$ solutions were 0,25 and $0,50 \%$ weigh; $\mathrm{KOH}$ solutions were 0,35 and $0,70 \%$ weigh).

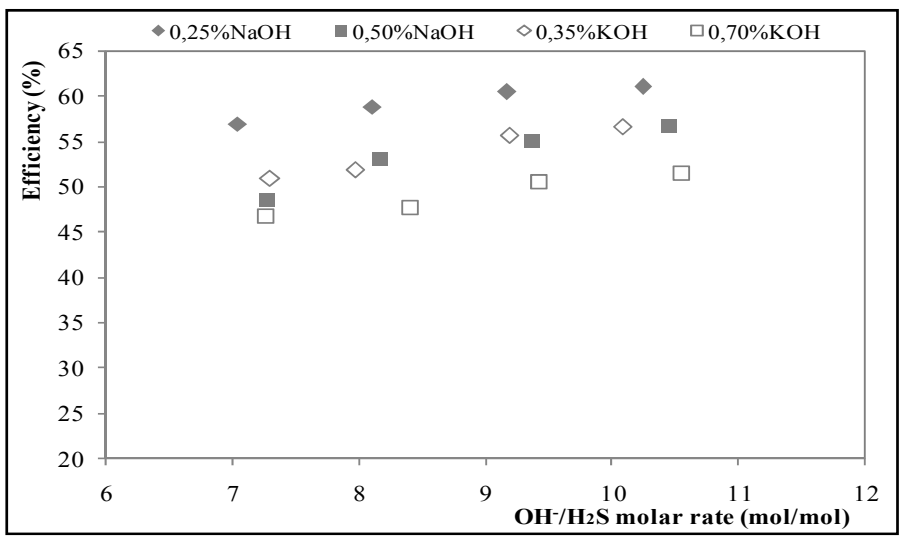

Figure 1. Efficiency of $\mathrm{H}_{2} \mathrm{~S}$ absorption as a function of the $\mathrm{OH}^{-1} / \mathrm{H}_{2} \mathrm{~S}$ molar rate (Pressure: 4 bar; contact time: $0,12 \mathrm{~s}$; gas flow rate: $0,8 \mathrm{Nm}^{3} / \mathrm{h}$; $\mathrm{CO}_{2}$ content of gas mixture: $20 \%$ vol.; $\mathrm{H}_{2} \mathrm{~S}$ content of gas mixture $105 \mathrm{ppmv}$ )

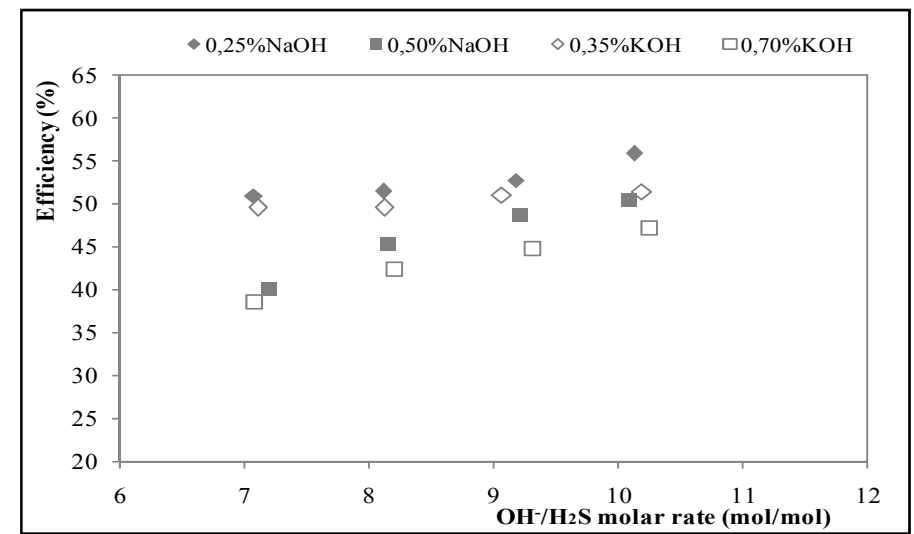

Figure 2. Efficiency of $\mathrm{H}_{2} \mathrm{~S}$ absorption as a function of the $\mathrm{OH}^{-1} / \mathrm{H}_{2} \mathrm{~S}$ molar rate (Pressure: 6bar; contact time: $0,17 \mathrm{~s}$; gas flow rate: $0,8 \mathrm{Nm}^{3} / \mathrm{h} ; \mathrm{CO}_{2}$ content of gas mixture: $20 \%$ vol.; $\mathrm{H}_{2} \mathrm{~S}$ content of gas mixture: 105ppmv) 


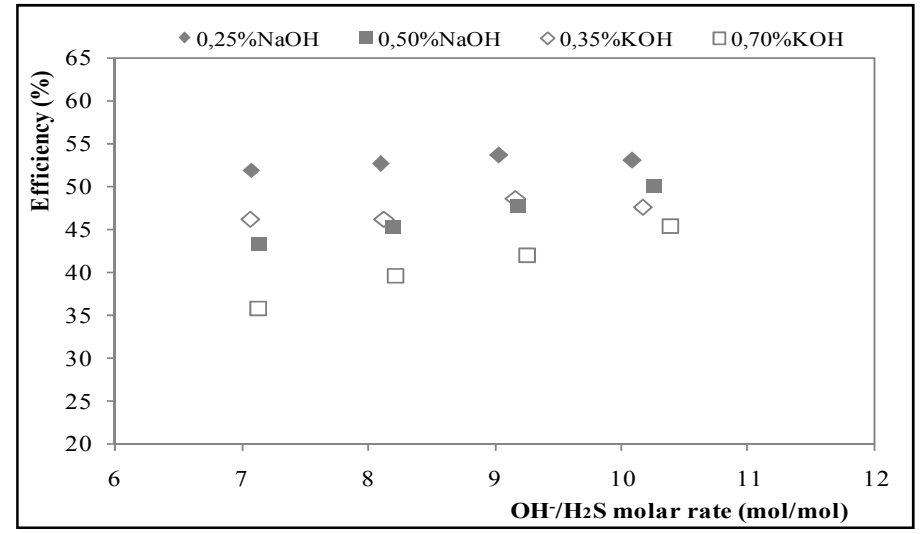

Figure 3. Efficiency of $\mathrm{H}_{2} \mathrm{~S}$ absorption as a function of the $\mathrm{OH}^{-} / \mathrm{H}_{2} \mathrm{~S}$ molar rate (Pressure: 8 bar; contact time: $0,22 \mathrm{~s}$; gas flow rate: $0,8 \mathrm{Nm}^{3} / \mathrm{h} ; \mathrm{CO}_{2}$ content of gas mixture: $20 \%$ vol; $\mathrm{H}_{2} \mathrm{~S}$ content of gas mixture: $105 \mathrm{ppmv}$ )

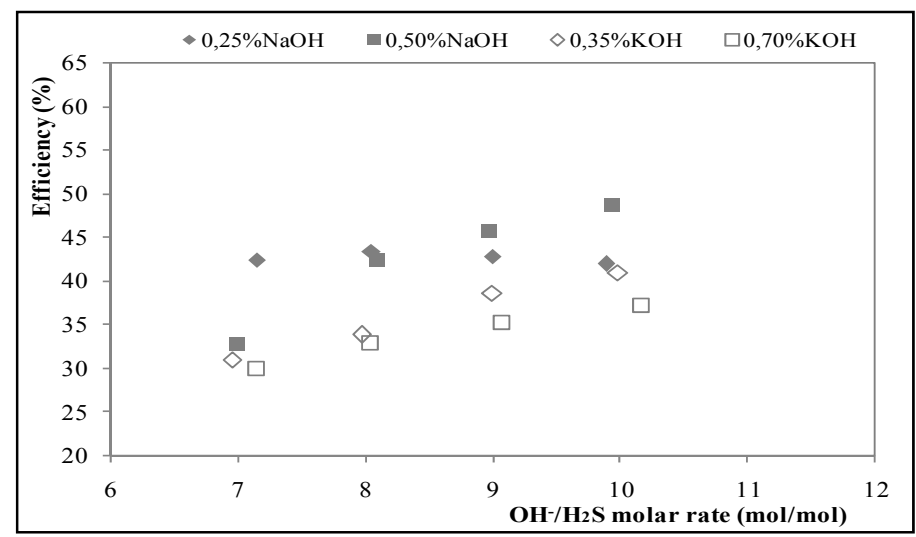

Figure 4. Efficiency of $\mathrm{H}_{2} \mathrm{~S}$ absorption as a function of the $\mathrm{OH}-/ \mathrm{H} 2 \mathrm{~S}$ molar rate (Pressure 10bar; contact time $0,27 \mathrm{~s}$; gas flow rate $0,8 \mathrm{Nm}^{3} / \mathrm{h} ; \mathrm{CO}_{2}$ content of gas mixture: $20 \%$ vol.; $\mathrm{H}_{2} \mathrm{~S}$ content of gas mixture: $105 \mathrm{ppmv}$ )

As seen in Figures 1-4, reduction of pressure and contact time causes improvement in efficiency in the tested range. This is true for all tested absorbents. The efficiency of operating was able to improve up to $20 \%$ due to decrease of contact time 0,15 s and of pressure 6 bar.

\section{Impact of contact time and gas flow rate at a constant pressure}

The contact time reduces together with increase of volumetric gas flow rate at a constant pressure. Measurements were executed with two different gas flow rate $\left(0,8\right.$ and $\left.1,3 \mathrm{Nm}^{3} / \mathrm{h}\right)$. The results are shown in Figure 5 . 
STUDY OF SELECTIVE HYDROGEN SULFIDE ABSORPTION BY COMPARING ...

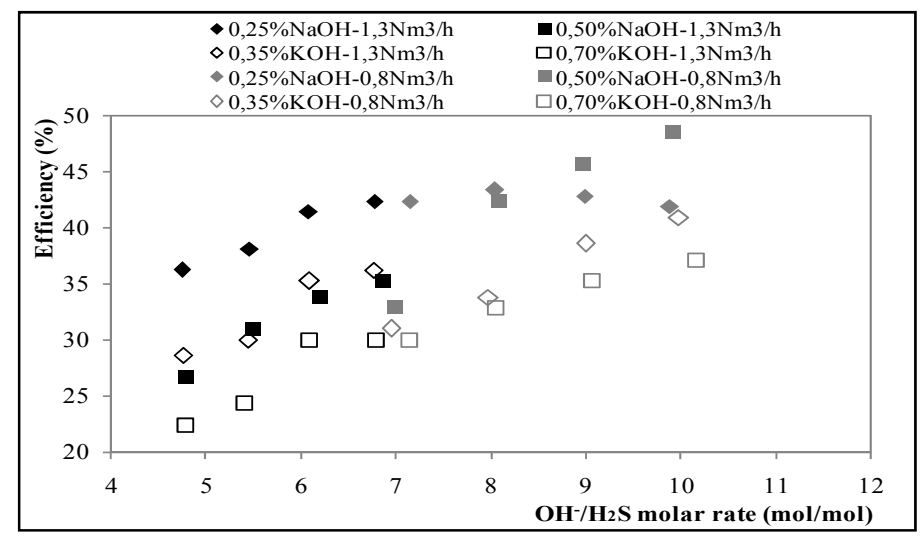

Figure 5. Efficiency of $\mathrm{H}_{2} \mathrm{~S}$ absorption as a function of the $\mathrm{OH}^{-} / \mathrm{H}_{2} \mathrm{~S}$ molar rate (Pressure: 10bar; $\mathrm{CO}_{2}$ content of gas mixture: $20 \%$ vol.; $\mathrm{H}_{2} \mathrm{~S}$ content of gas mixture: 105ppmv)

The results are easily comparable principally at $7 \mathrm{~mol} \mathrm{OH}^{-} / \mathrm{mol} \mathrm{H}_{2} \mathrm{~S}$ ratio. We can see that the higher gas flow rate $\left(1,3 \mathrm{Nm}^{3} / \mathrm{h}\right)$ and shorter contact time $(0,19 \mathrm{~s})$ caused higher efficiency. Also in this case it is proved that reduce of contact time favors for selective $\mathrm{H}_{2} \mathrm{~S}$ absorption. In this examination the difference of two volumetric gas flow rate was $0,5 \mathrm{Nm}^{3} / \mathrm{h}$ (this difference in contact time $0,08 \mathrm{~s}$ ) and it can cause up to $5 \%$ difference in efficiency.

\section{Impact of $\mathrm{CO}_{2}$ content}

The measurements were performed three different gas mixtures in order to know the effect of $\mathrm{CO}_{2}$ content. The results are shown in Figure 6 in case of $0,25 \%$ weigh $\mathrm{NaOH}$ and $0,35 \%$ weigh $\mathrm{KOH}$ absorbents.

According to Figure $6,10 \% \mathrm{CO}_{2}$ content was able to cause $50 \%$ decrease of efficiency compared to $0 \% \mathrm{CO}_{2}$ even if the contact time is few tenths sec magnitude $(0,27 \mathrm{~s})$. However, increase of $\mathrm{CO}_{2}$ content from $10 \%$ to $20 \%$ did not generate further significant decrease of efficiency. The reason of this experience is that the contact time, the surface, the droplet size and the molar amount of absorbent set a limit to gas absorption. (During measurements the difference of inlet and outlet $\mathrm{CO}_{2}$ level was below $1 \%$ vol.) 


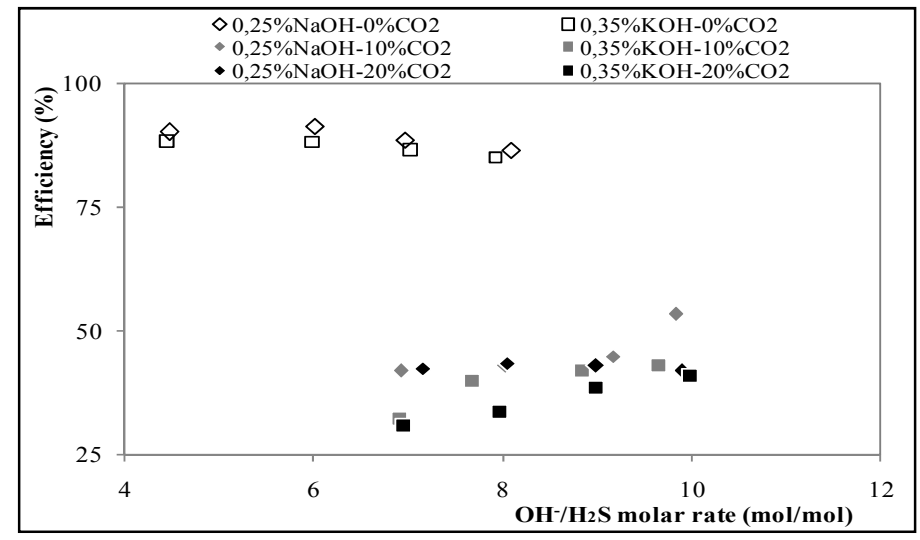

Figure 6. Efficiency of $\mathrm{H}_{2} \mathrm{~S}$ absorption as a function of the $\mathrm{OH}^{-} / \mathrm{H}_{2} \mathrm{~S}$ molar rate (Pressure: 10bar; contact time: $0,27 \mathrm{~s}$; gas flow rate: $0,8 \mathrm{Nm}^{3} / \mathrm{h} ; \mathrm{H}_{2} \mathrm{~S}$ content of gas mixture: 105ppmv)

\section{Impact of absorbent material quality and concentration}

Every diagram (Figure 1-6) in this paper presents the effectiveness of two kinds of alkali absorbent in various conditions. Every figure shows that the efficiency results by using the $\mathrm{NaOH}$ were better absorbent and not the $\mathrm{KOH}$ under experimental conditions. This experience can be explained by the different molar mass of two compounds. $\mathrm{KOH}$ has a bigger molar mass $(56,1 \mathrm{~g} / \mathrm{mol})$ compared with $\mathrm{NaOH}(40,0 \mathrm{~g} / \mathrm{mol})$. Consequently in case of $\mathrm{KOH}$ the particular molar concentration solution will have higher density and also liquid-side resistance. The big liquid-side resistance is a disadvantage in the tested contact time interval. The absorption in a higher density solution belongs to a longer contact- and dissolution time demand. Besides density, viscosity and surface tension of liquid phase determine the work of atomization and for this reason quality of atomization is influenced.

Further measurements were made about liquid-side resistance by using various concentration solutions of alkali absorbents (Figure 1-5). The efficiency of $\mathrm{H}_{2} \mathrm{~S}$ absorption was better by using the lower concentration of absorbents in almost every tested point. Also this observation supports the previous conclusion about density of absorbent, contact time requirement and liquid-side resistance.

Figure 4 seems to be an extreme case. There are some measuring points, where it can be seen, that applying of the more concentrated absorbent was the more useful in contrast to more dilute one. Therefore, investigation of the created surface and the droplet size is necessary (Table 1). 


\section{Investigation of reaction surface and droplet size}

The size of droplets and created surface are very important parameters in the efficiency of the $\mathrm{H}_{2} \mathrm{~S}$ absorption. By using NukiyamaTanasawa equation the droplet size can be defined easily, if we are aware of surface tension, density, viscosity and volume flow rate of absorbent, volume flow rate of gas phase and relative velocity between two phases [15]. If we assume that the formed droplets are spherical, also the reaction surface can been defined based on the diameter of droplets and volume flow rate of absorbent. Table 1 shows the surface and droplet size information in case of Figure 4 by using 0,25 and $0,50 \%$ weigh $\mathrm{NaOH}$ absorbents.

Table 1. Investigation of reaction surface and droplet size on the absorption efficiency (Pressure 10bar; contact time $0,27 \mathrm{~s}$; gas flow rate $0,8 \mathrm{Nm}^{3} / \mathrm{h} ; \mathrm{CO}_{2}$ content of gas mixture: $20 \%$ vol.; $\mathrm{H}_{2} \mathrm{~S}$ content of gas mixture: $105 \mathrm{ppmv}$ )

\begin{tabular}{|c|c|c|c|c|c|c|}
\hline \multirow[b]{2}{*}{$\begin{array}{c}\mathrm{NaOH} / \mathrm{H}_{2} \mathrm{~S} \\
\text { molar ratio } \\
\text { (mol/mol) }\end{array}$} & \multicolumn{3}{|c|}{$0,25 \%$ weigh $\mathrm{NaOH}$} & \multicolumn{3}{|c|}{$0,50 \%$ weigh $\mathrm{NaOH}$} \\
\hline & $\begin{array}{l}\text { Drop } \\
\text { size } \\
(\mu \mathrm{m})\end{array}$ & $\begin{array}{c}\text { Surface } \\
\left(\mathrm{m}^{2}\right)\end{array}$ & $\begin{array}{c}\text { Efficiency } \\
(\%)\end{array}$ & $\begin{array}{l}\text { Drop } \\
\text { size } \\
(\mu \mathrm{m})\end{array}$ & $\begin{array}{c}\text { Surface } \\
\left(\mathrm{m}^{2}\right)\end{array}$ & $\begin{array}{c}\text { Efficiency } \\
(\%)\end{array}$ \\
\hline 7 & 11 & 64,3 & 42 & 4 & 79,0 & 33 \\
\hline 8 & 13 & 62,6 & 43 & 5 & 76,3 & 42 \\
\hline 9 & 15 & 60,6 & 43 & 6 & 75,7 & 46 \\
\hline 10 & 17 & 59,0 & 42 & 7 & 74,2 & 49 \\
\hline
\end{tabular}

Theoretically, the increasing reaction surface and $\mathrm{NaOH} / \mathrm{H}_{2} \mathrm{~S}$ molar ratio have a beneficial effect on efficiency of $\mathrm{H}_{2} \mathrm{~S}$ absorption. It can be observed that the surface was larger by using $0,50 \%$ weigh $\mathrm{NaOH}$ absorbent than $0,25 \%$ weigh in every single point of tested range. Nevertheless the $0,25 \%$ weigh solution was the more efficient absorbent by applying $7 \mathrm{~mol} \mathrm{NaOH} / \mathrm{mol} \mathrm{H}_{2} \mathrm{~S}$ caustic excess. It is also important to notice that the efficiency of operation can be improved over the decrease of surface and increase of drop size. Based on the observations, the following conclusions can be drawn: the efficiency can be increased together with alkali excess not only to reach of the maximum reaction surface; and better efficiency can be achieved by using the lower concentration absorbent even if the reaction surface is smaller because of the less liquid-side resistance and dissolution time requirement.

\section{CONCLUSIONS}

As a summary of the experiences the following conclusions can be drawn. The efficiency of $\mathrm{H}_{2} \mathrm{~S}$ removal improves by reduce of contact time 
$(0,12-0,27 \mathrm{~s})$ because it redounds to selective absorption of $\mathrm{H}_{2} \mathrm{~S}$. (The contact time is changeable by pressure or gas flow rate.) If the contact time is such short, it is necessary that the liquid-side resistance should be small. Therefore, it is recommended to use low density, dilute absorbents for the operation. Also, the comparative study of $\mathrm{NaOH}$ and $\mathrm{KOH}$ showed that the $\mathrm{NaOH}$ is the better absorbent in the examined conditions because it has a lighter molar mass. Consequently, in case of $\mathrm{KOH}$ the particular molar concentration solution will have higher density and also liquid-side resistance. As it is an atomization method, we have to take into consideration the size of surface and droplets, as well. Theoretically, enhancements of $\mathrm{OH}^{-} / \mathrm{H}_{2} \mathrm{~S}$ molar ratio and surface have beneficial effect for efficiency. Improvement of efficiency is feasible not only up to reaching the maximum surface by rise of $\mathrm{OH}-/ \mathrm{H}_{2} \mathrm{~S}$ alkali excess. In addition, better efficiency can be achieved by using the lower concentration of absorbent even if the reaction surface is smaller at a given $\mathrm{OH}^{-} / \mathrm{H}_{2} \mathrm{~S}$ molar ratio. It depends on the difference of droplet- and surface size, and also difference of concentrations of absorbents at constant gas flow rate and pressure. The reason is the less liquid-side resistance and dissolution time requirement. Harmful effect of $\mathrm{CO}_{2}$ level in gas mixtures is very significant for the efficiency of operation even if the contact time is just few tenths sec magnitude $(0,27 \mathrm{~s})$. The effect and content of $\mathrm{CO}_{2}$ do not change directly proportional way because the contact time, the surface, the droplet size and the molar amount of absorbent set a limit to gas absorption.

\section{EXPERIMENTAL SECTION}

Examinations were implemented by use of two different concentrations of $\mathrm{NaOH}$ and $\mathrm{KOH}$ absorbents (Table 2) and three different compositions of gas mixture (Table 3 ).

Table 2. The concentration and density of absorbents

\begin{tabular}{|c|c|c|c|c|}
\hline $\begin{array}{c}\text { Concentration of } \\
\text { absorbents } \\
\left(\mathrm{mol} / \mathrm{dm}^{3}\right)\end{array}$ & $\begin{array}{l}\text { Weight } \% \text { of } \\
\text { NaOH solution } \\
\text { (\% weigh) }\end{array}$ & $\begin{array}{c}\text { Density of } \\
\mathrm{NaOH} \text { solution } \\
\left(\mathrm{g} / \mathrm{cm}^{3}\right)\end{array}$ & $\begin{array}{c}\text { Weight } \% \text { of } \mathrm{KOH} \\
\text { solution } \\
\text { (\% weigh) } \\
\end{array}$ & $\begin{array}{c}\text { Density of KOH } \\
\text { solution } \\
\left(\mathrm{g} / \mathrm{cm}^{3}\right) \\
\end{array}$ \\
\hline 0,06 & 0,25 & 1,0011 & 0,35 & 1,0015 \\
\hline 0,12 & 0,50 & 1,0039 & 0,70 & 1,0046 \\
\hline
\end{tabular}

Table 3. Composition of gas mixtures

\begin{tabular}{|c|c|c|}
\hline $\begin{array}{c}\text { Calculated } \mathbf{N}_{\mathbf{2}} \text { content } \\
\text { (\% vol.) }\end{array}$ & $\begin{array}{c}\text { Measured } \mathbf{C O}_{\mathbf{2}} \text { content } \\
\text { (\% vol.) }\end{array}$ & $\begin{array}{c}\text { Measured } \mathbf{H}_{\mathbf{2}} \mathbf{S} \text { content } \\
\text { (ppmv) }\end{array}$ \\
\hline 99,9895 & 0,0 & 105 \\
\hline 89,3895 & 10,6 & 105 \\
\hline 79,9895 & 20,0 & 105 \\
\hline
\end{tabular}


The schematic representation of the experimental apparatus is given in Figure 7.

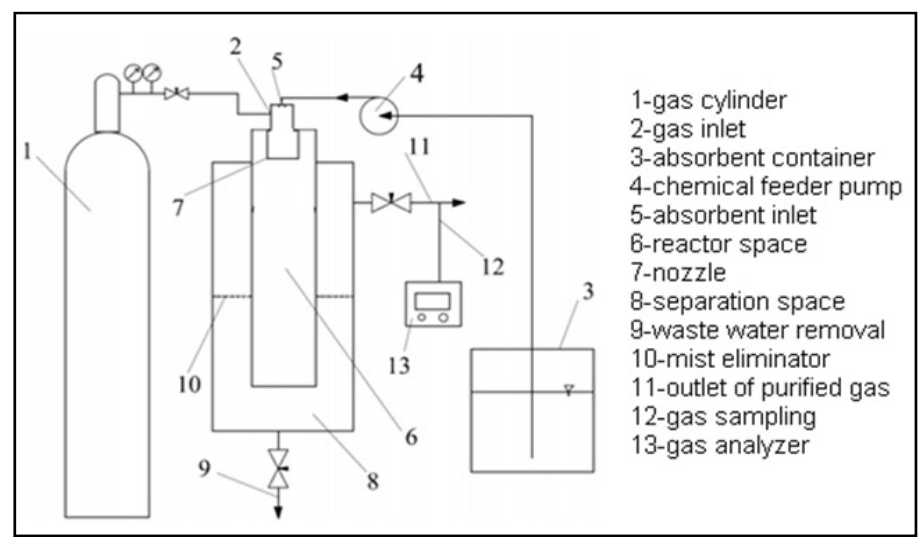

Figure 7. The special experimental appliance [5]

Applying of this special reactor provides the opportunity to minimize the contact time $(<1 \mathrm{~s})$ between gas and liquid phases. The gas stream atomizes the fed absorbent to droplets through the nozzle. The contact of two different phases is very intensive in the reactor zone. The contacted gas and liquid get from the reactor zone to the separation. In the separation zone the waste absorbent can be removed from the system after the mist eliminator. The $\mathrm{CO}_{2}(\%$ vol. $)$ and $\mathrm{H}_{2} \mathrm{~S}(\mathrm{ppmv})$ content of outlet gas is measured continuous by using Drager X-am 7000 gas analyzer [5].

\section{ACKNOWLEDGMENTS}

We are grateful to the MOL for financial supporting this project.

\section{REFERENCES}

1. L. Grazia, Journal of Cleaner Production, 2016, 131, 364.

2. R. Álvarez-Cruz, B.E. Sánches-Flores, J. Torres-González, R. Antano-López, F. Castaneda, Fuel, 2012, 100, 173.

3. N. Tippayawong, P. Thanompongchart, Energy, 2010, 35, 4531.

4. E. Üresin, H. I. Sarac, A. Sarioglan, S. Ay, Process Safety and Environmental Protection, 2015, 94, 196. 
5. Á. Vágó, D. Rippel-Pethö, G. Horváth, I. Tóth, K. Oláh, Hungarian Journal of Industrial Chemistry, Veszprém, 2011, 39 (2), 283.

6. É. Molnár, D. Rippel-Pethő, G. Horváth, Z. Hodai, R. Bocsi, J. Bobek, Periodica Polytechnica Chemical Engineering, 2016, 60(2), 74.

7. J. B. Siemak, M. Gelbs, SPE California Regional Meeting, 1985, 13650-MS

8. R. G. Heltz, Al L. Rocklin, U.S. Patent, US2747962 A, 1956.

9. E. Bendall, R. C. Aiken, F. Mandas, AlChE Journal, 1983, 29(1), 66.

10. K. T. Hsieh, R. C. Aiken, Chemical Engineering Communication, 1988, 31, 367.

11. D. Mamrosh, C. Beitler, K. Fisher, S. Stem, Gas Processing Developments, 2008, Special Report, 69.

12. V. Bontozoglou, A. Karabelas, Industrial and Engineering Chemical Research, 1993, 32(1), 165.

13. A. Trupin, A. Couvert, A. Laplanche, A. Paillier, Chemical Engineering and Processing, 2008, 47, 886.

14. Y. Tamhankar, B. King, J. Whiteley, K. McCarley, T. Cai, M. Resetarits, C. Aichele, Separation and Purification Technology, 2015, 156, 311.

15. D. S. F. Atkinson, W. Strauss, Journal of the Air Pollution Control Association, 1978, 28(11), 1114.

16. A. L. Kohl, R. B. Nilsen, Gas Purification, Houston, Gulf Publishing Company, 1997. 